\title{
Acoustic of lightweight timber buildings: a review
}

Marco Caniato ${ }^{1,3}$, Federica Bettarello ${ }^{2}$, Alessio Ferluga ${ }^{1}$, Lucia Marsich ${ }^{1}$, Chiara Schmid ${ }^{1}$, Patrizio Fausti $^{3}$

${ }^{1}$ Engineering and Architecture Department, University of Trieste, via Valerio 6/a, 34127 Trieste, Italy

${ }^{2}$ AcusticaMente Designers Team, via Garibaldi 13/b, 31015 Conegliano (TV), Italy

${ }^{3}$ Department of Engineering, University of Ferrara, via Saragat 1, Ferrara, Italy

* corresponding author: mcaniato@units.it; +393473167278

\section{Abstract}

This paper presents a literature overview of the acoustic studies dedicated to lightweight wooden constructions. The reviewed articles contain prediction models, laboratory and field measurements, finite element or computational investigations as well as subjective survey describing the vibroacoustic behaviour of a large range of wooden structures. The review analyses different type of timber constructions and investigates the acoustic research methodologies highlighting the following aspects: airborne sound insulation, impact noise reduction, flanking transmissions, human perceptions and pros and cons of the presented methods. Furthermore, an in-depth analysis of impact noise of bare floors focuses on how impact sound reduction could not be as efficient as in heavyweight constructions; the comparison between the different approaches on prediction of airborne sound insulation of multilayer timber partitions compared to traditional heavy building materials is shown. Finally a subjective method survey is provided, underlining the weakest point of timber buildings: low frequency sound insulation.

Keywords: Sustainable buildings; acoustic; timber building; precast energy saving panels

\section{Introduction}

Lightweight buildings are present worldwide and their market trend is growing, pushed by the Kyoto protocol [1]. They allow $\mathrm{CO}_{2}$ storage since wood is widely used as it is renewable and environmental friendly raw material. Generally, these constructions are built within industry plants where very few waste and little energy consumption are possible and allowed. Furthermore, prefabrication often means high quality: educated workmanship is used and CE certifications are required and provided.

The production methods generally include CAD-CAM technologies, permitting new and complex architectural shape, concept and tendencies. The speed of assembly is an interesting point since it is possible to obtain multi-storey buildings containing prefabricated volumes. As a matter of fact, 
within two weeks, high constructions could be erected thanks to the previous in-depth design and high industrial production precision. In Figure 1 an example of wall assembly is shown: from a) to c) the precast panel fits perfectly into the spaces of the flanking walls. Figure $1 \mathrm{~d}$ ) highlights the great precision on the production. The walls (or floors) route start from the truck and finishes with long screw fixation upon the final position falling in its pre-designed location. This indicates the speed and the high precision of assembly typical of timber precast buildings; as a results, these properties attract many stakeholders like designers, builders and lay people.
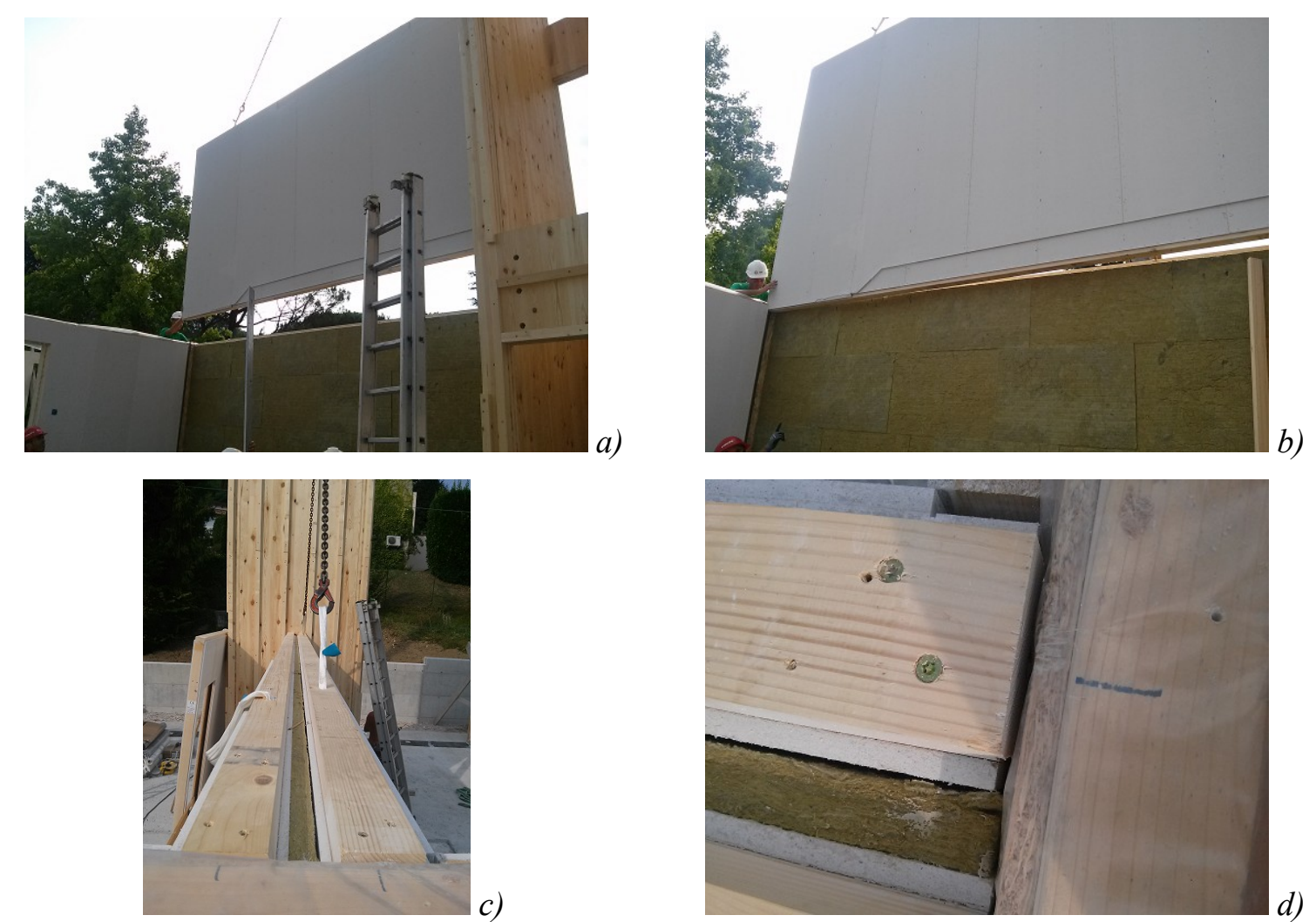

Figure 1 - Example of wall assembling in a multi-storey light weight timber building. From a) to c) the panel is let down using crane. In d) the high requested precision and accuracy is highlighted.

Nevertheless, the technological diversity distinguishing wooden constructions (frame, CLT, etc.) makes homogenization of forecasting calculation methods more difficult concerning sound insulation parameters compared to traditional massive buildings (concrete, masonry, etc).

In few years multi-storey timber constructions were erected e.g. in Europe [3], Japan [4], New Zeeland [5] and consequently many issues are grown. Over the last period many researchers have tried to handle with sound insulation and reduction topics but what they found is very difficult to understand at a first sight: timber structures are various. Every manufacturer, industrial plant or designer present different solutions using the same raw constructing materials and features: wood, wool, boards. Besides, multiple joints, screws, fastening and locking are possible and every precast wall, floor or roof present different types of junctions. In Figure 2 it is possible to notice different kind of screw or fastening elements used in the same joints but in different buildings. This fact 
highlights the difficulty to standardize or predict the acoustic behaviour of joists since it is impossible to forecast how they will be fastened. The different fixing element properties like length, number of possible screws, shape etc. implies a diverse constrains and wall-floors junctions. These facts determine many possible vibrations propagation paths and flanking transmissions. For every wall or floor many different elements could be placed so the in situ behaviour could vary individually from one connection to another.
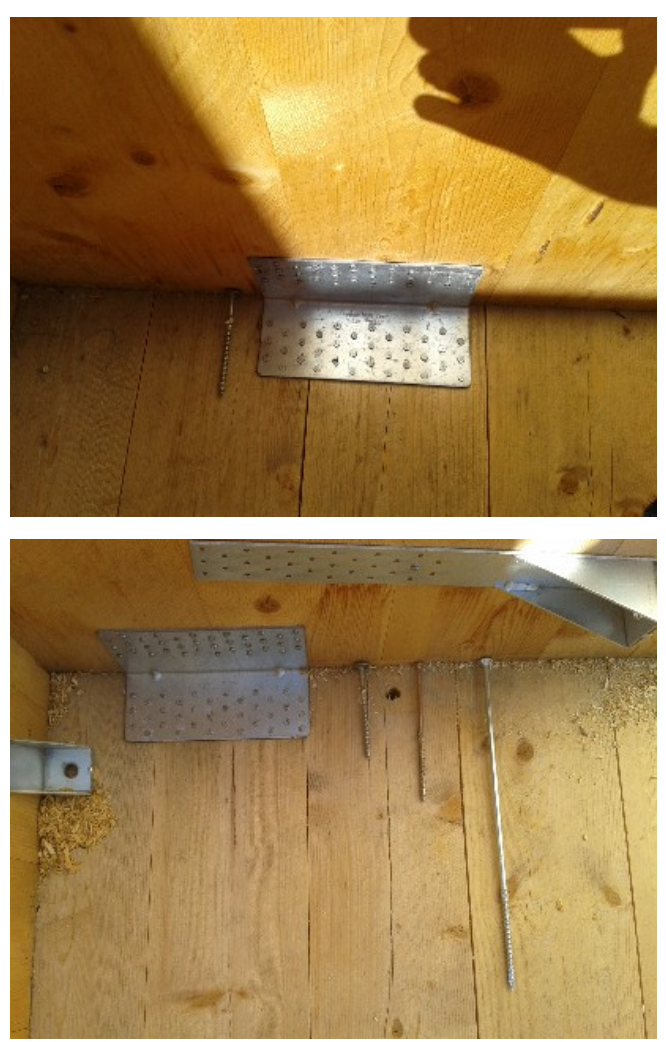
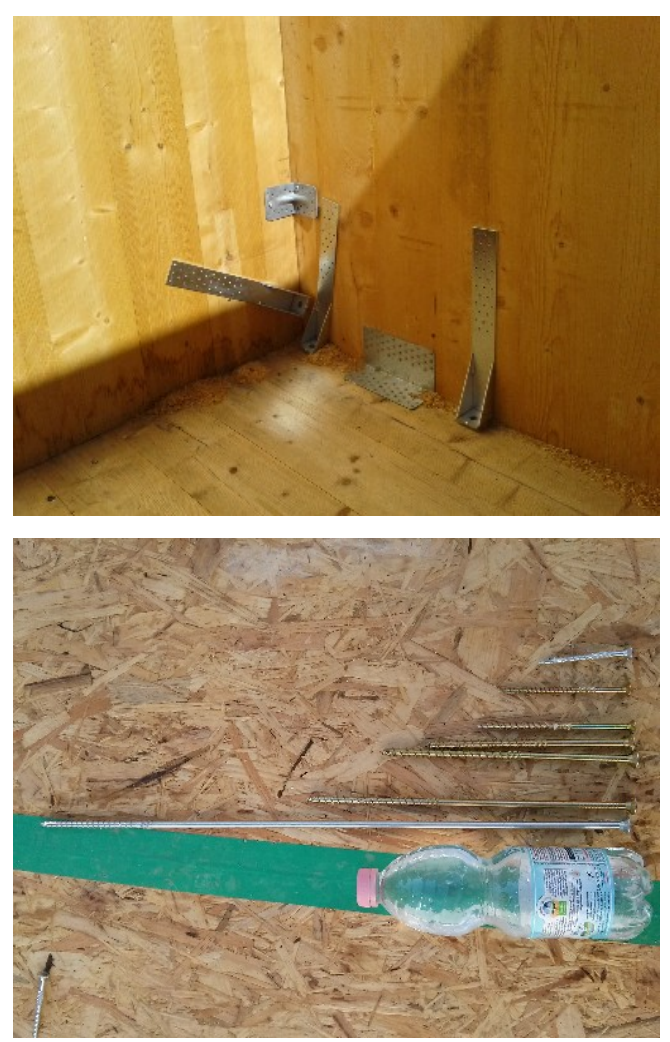

Figure 2 - different types of screws, joints and junctions used with precast timber panels. Pictures from different building constructions

Furthermore, applying the same prediction methods or analysis used for heavy weight constructions it could be rather approximated. Bettarello et al. [6] show how different bare floors (heavy weight, beams and pots and lightweight ones) present dissimilar impact sound pressure level and the consequent floating floor sound reduction [7] could not assure the same results.

It is possible to find the same conclusion for vertical partitions too [8]-[10]. About these topics the authors demonstrate how sound insulation is affected by low frequencies and underline the difficulty to predict composite walls insulation [11]. In the same paper, many prediction methods applicable for sound insulation in timber structure are described. The study divides them in two different categories: i) energy combined with empirical knowledge and data approach and ii) deterministic, numerical and analytical approach. The overview concludes that there are good models handling advantages, radiation and periodicity and the authors intend to use the latter as suitable for timber structures. 
From subjective point of view, many investigations are possible since it is not clear if people living inside lightweight buildings feel better wellbeing compared to heavy weight structures [12].

The features of wooden constructions can vary a lot from one manufacturer to another and researchers typically assess one particular structure only, which they chose randomly. This leads to highly contrasting outcomes and confusion as to whether or not wooden structures perform better than traditional structures.

Prediction methods developed for traditional structures are moreover frequently applied to wooden ones, which is obviously questionable. How many types of wooden structure have been studied? How many of them accurately and satisfactorily?

All papers on this topic are therefore collected and reviewed here in order to better understand wooden structures, conduct a general assessment of what is known and draw a number of conclusions.

We conducted an extensive literature review using databases such as ISI Web of Knowledge, Science Direct, Scopus, Google Scholar and the published proceedings of world congress of the last 4 years.

According to figure 3 and Table 1, the paper is divided in two different sub-sections which analyse separately diverse technologies. In the first section, papers dedicated to impact sound pressure level both of bare and treated floors are presented. Afterwards, airborne sound pressure level, new prediction methods and subjective response are investigated. The overview ends with final evaluations and conclusions.

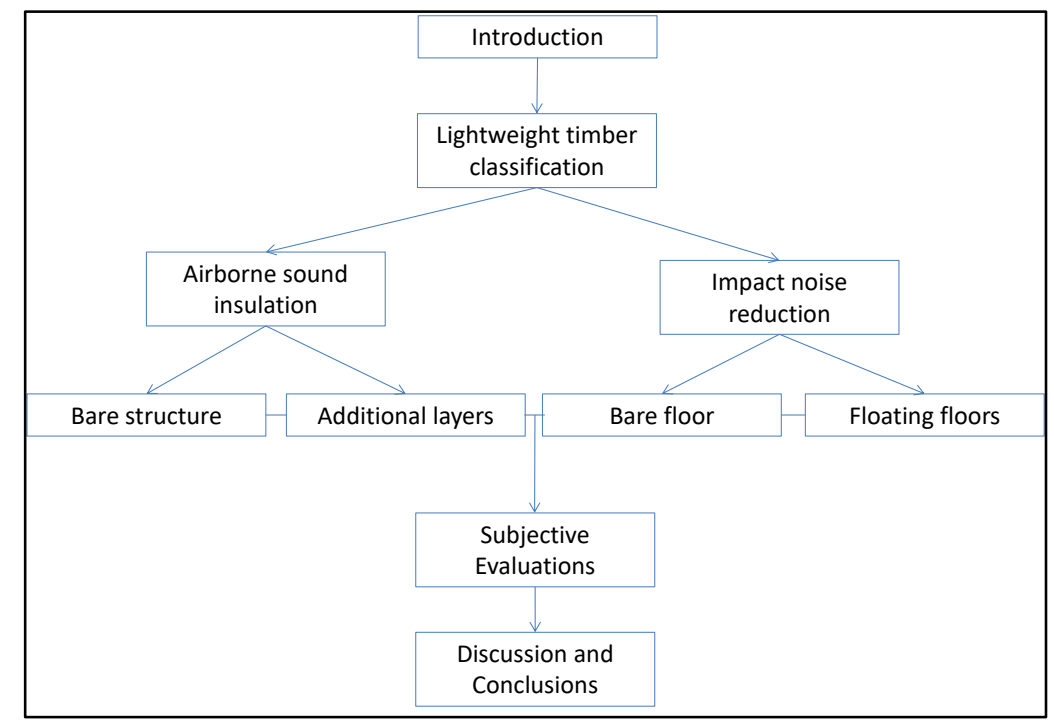

Figure 3 - flowchart of the paper structure

It is worthy to point out that, due to the rapid development of lightweight timber building acoustic research, there is a lack of consistency in sampling and approaching techniques used to quantify the measured or predicted parameters. As a result of the large variety in techniques applied, 
comparison of reported outcomes between studies is often impossible or requires additional calculations based on assumptions.

The majority of these method inconsistencies can be related to (i) differences in the approach of measurements techniques, (ii) extremely various types of involved timber structures and (iii) differences in aims and scopes of diverse researches.

As an example, the lack of an unequivocal structure-based definition of bare timber floor or wall has resulted in the reporting of several different frame or continuous constructions in literature, all using the same terms: timber (or wooden, or lightweight) buildings. In practice, this means that the results of a substantial body of timber buildings literature cannot be compared directly.

The main scopes of this literature overview are to understand (1) the state-of-art of the results related to acoustic research of lightweight timber buildings and (2) to understand different construction performance.

This was achieved by analysing available literature to: (i) provide an in-depth evaluation of the impact sound pressure levels of bare floors and study the reduction provided by different reducing technologies such as floating floors and ceilings as well as analysing the influence of low frequencies (section 2), (ii) discuss the occurrence, distribution and influences of layers on airborne sound insulation and the related predicting methods (section 3) and (iii) make a comprehensive evaluation on subjective response of people living inside these buildings (section 4).

A graphical summary of how many possible structures is summarized in Table 1 wherein different structures are listed both with picture and text. There are four categories grouping different structures as follows (see Table 1):

- type A: wood structure not included in plaster or fibre board;

- type B: glulam beams with boards screwed on top

- type C: homogenous wooden structure

- type D: open-truss structures

Since all papers deal with only one type at a time (or even one particular feature of a single kind), this classification is necessary in order to sort and group papers and studies based on structure selection.

Table 1 - Types of lightweight bare partitions included in literature

\begin{tabular}{|c|c|c|}
\hline Code & Description & Graphic representation (from papers) \\
\hline A & $\begin{array}{l}\text { Timber-concrete floor. It } \\
\text { consists of timber structure } \\
\text { of glulam beams with } \\
\text { wood/plaster board(s) } \\
\text { screwed on it. An } \\
\text { additional layer of concrete }\end{array}$ & 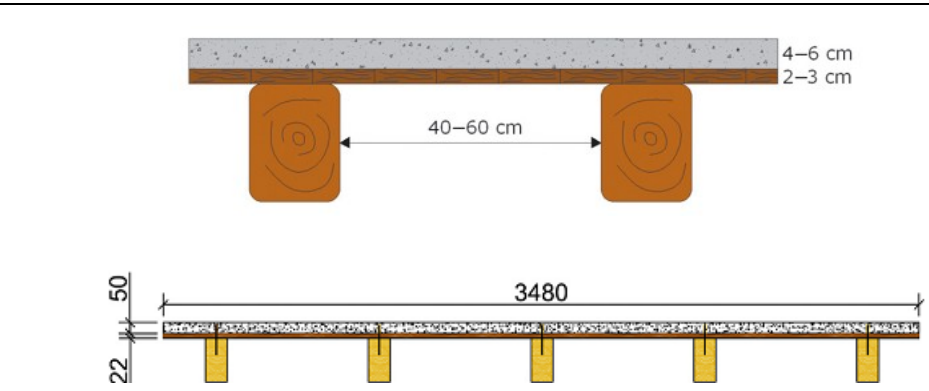 \\
\hline
\end{tabular}




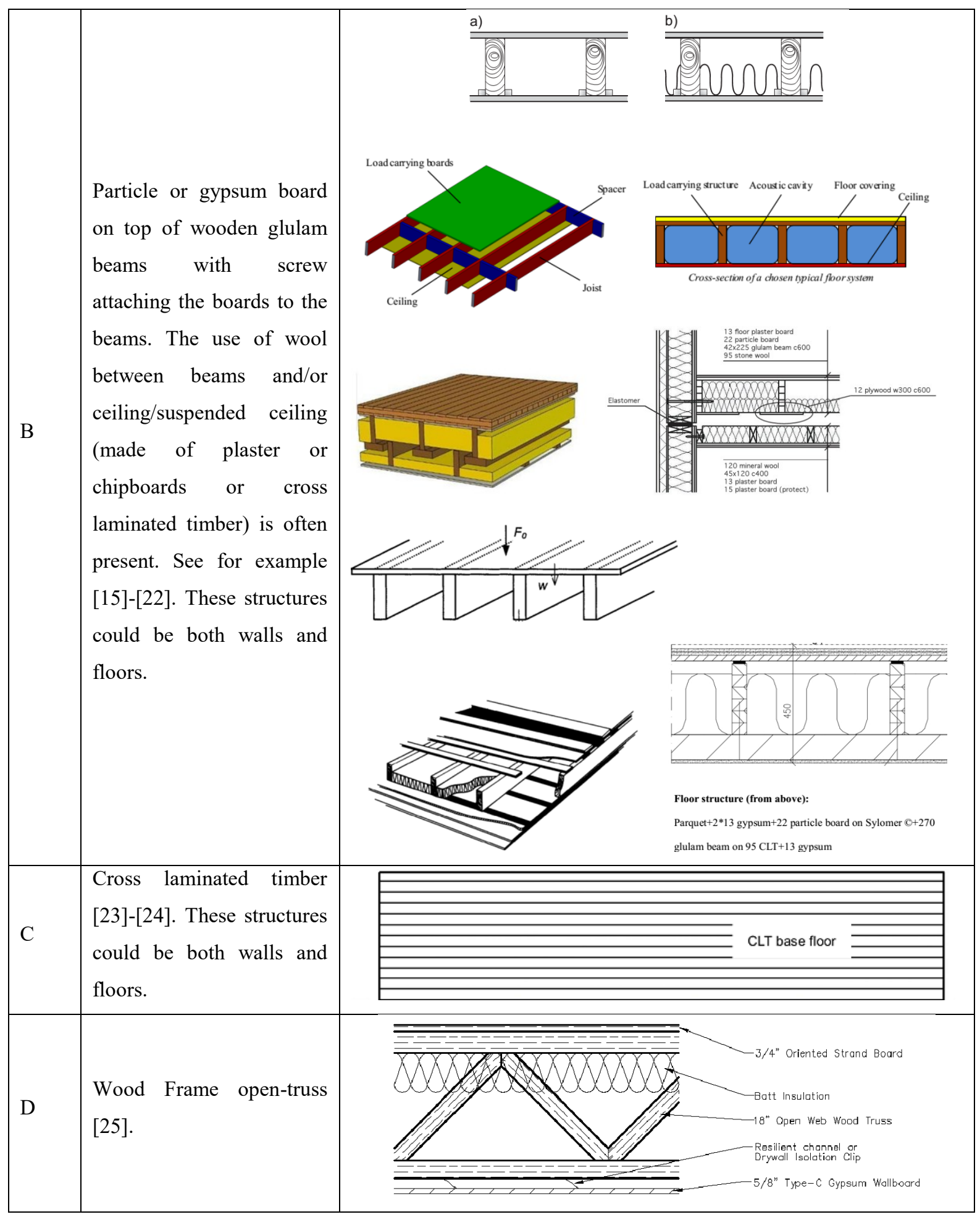

\section{Impact sound}

Many studies are present in literature concerning the determination of bare partition performance as well as floating floor-suspended ceilings effects and subjective response to vibrational excitation. The determination of frequency trend of bare floor is of paramount importance [6]-[26]. The method presented in EN 12354-2 standard [13] provides the possible impact sound reduction according to equation (1): 


$$
L_{n, W}=L_{n, W, e q}-\Delta L_{W}
$$

where $\mathrm{L}_{\mathrm{n}, \mathrm{w}}$ is the resulting impact noise $(\mathrm{dB}), \mathrm{L}_{\mathrm{n}, \mathrm{w}, \mathrm{eq}}$ is the impact noise of the bare floor $(\mathrm{dB}), \Delta \mathrm{L}_{\mathrm{w}}$ is the impact sound pressure level reduction $(\mathrm{dB})$.

It is evident that the bare floor acts as starting point and so the type of partitions is the primary source. In timber structures there are many different technologies.

The common issues are focused on low frequency range: impact sound pressure level is higher in lightweight wooden buildings than in heavyweight ones. One of the most troubleshooting in residential apartments is attributed to the noise produced by walking [26].

Type A

The A technology is widely studied and used in Mediterranean country. Bettarello et Al. [6] performed in situ ISO tapping machine measurements in order to investigate the impact sound pressure level of three kinds of bare floor, including the type A. The results provide an empirical equation suitable to be used as input data for EN 12354-2 model. This equation takes in to account the frequency trend as follows:

$$
\begin{array}{ccc}
L_{n, \text { eq,avg }}=10.4 \log (f)+50 & (\mathrm{~dB}) & \text { for } \mathrm{f}<1600 \mathrm{~Hz} \\
L_{n, \text { eq,avg }}=-6.1 \log (f)+129 & (\mathrm{~dB}) & \text { for } \mathrm{f}>1600 \mathrm{~Hz}
\end{array}
$$

On the other hand Martins et al. [14] investigated the same structure using laboratory ISO tapping machine tests adding a floating floor on the top of the bare structure in order to study the influence of suspended ceiling. These results, compared with European requirements [28], demonstrate that the bare structure does not fulfil any limits while the addition of ceiling does.

Hiramatsu [29] tested a three-story full scale school within type A floor, using three different sources: car tyre, rubber ball and tapping machine. The results show a similar ISO tapping machine frequency trend compared to previous studies, but the other two sources, as expected [30]-[33], provide very different behaviours; the author concludes that the best source for A type is the car tyre conversely to Bettarello's outcomes [6].

\section{Type B}

The B technology is the most studied and presents a great number of variants. Types of lightweight bare partitions shown in Table 1 are only some representative case-studies and typologies. In order to point out which of the numerous parameters of type B floor are noteworthy, Brunskog and Hammer [15],[16] investigated the structure using analytical models, considering the excitation force and the interaction of ISO tapping machine on lightweight floors [30]. Their conclusions report the following considerations: 
- mineral wool (with different flow resistivity) in cavity reduces the impact noise for frequency above $250 \mathrm{~Hz}$

- different mass plates gives better performance than a single heavy plate

- the periodic distance of the beams influences low frequency range

- the construction depth decreases the impact noise; in addition when the wool is present the reduction could rise up to $15 \mathrm{~dB}$.

The most interesting aspect is that the low frequency effect is caused by the structure itself and it does not significantly vary if big changes (high density added layer, very thick suspended ceilings, etc.) are not applied on it. Coguenanff et al. [17] state that strong dominant modal behaviour is present below $200 \mathrm{~Hz}$. According to COST action FP90702 report [35], the wooden structures present a better insulation in middle and high frequency range than the heavy weight ones. As a consequence, the low frequency influence has to be further investigated. Johansson [22] carry out many tests on a series of timber floors arrangements in order to understand the influence of different layers and beams and conclude that in most cases when an improvement is seen at low frequency range, the structures show worse behaviour at high frequencies.

Sjöström et al. [36] focused on top layer consisting of one or two attached chipboards. Using vibration measurements method in low frequency range $(10-600 \mathrm{~Hz})$ they conclude that the low frequency energy propagation is lowered by the second not overlapping layer. Nevertheless as previously found [22] at higher range this benefit disappears.

Chung et al. [37] measured several examples of lightweight timber based floor/ceiling systems, having higher sound insulation performances than those based on concrete slab. By means of laboratory vibration measurements they obtain the resonance frequencies and the modal shapes. Then three upper layers were put on the top of the basic structures. The conclusions (using ISO tapping machine) show how the inclusion of sand-sawdust mixture layer provides effective vibration damping of the whole composite structure over a wide frequency range.

Späh et al. [38], [39] realized measurements with different sources, both in laboratory and in situ. ISO tapping machine, rubber ball and "real" sources (walking people) were used. Then a subjective survey was realized to compare which source is most appropriate to represent real walking noise. The results show how both rubber ball and ISO tapping machine are able to represent the real walking noise.

On the other hand Hiramatsu et al. [40] investigated floor impact sound insulation on a full scale timber construction, using rubber ball, car tyre and tapping machine. The results present some difficulties in the case of rubber ball source: many changes were found due to different source positions. Therefore, from the measurement method point of view, the excitation position needs to be taken into account.

Lentzen et al. [41] studied the flanking transmission issue. The authors state that the ISO 12354 [13] methods could fit only with heavy monolithic buildings. Therefore, the adaptations and points 
of interest for lightweight buildings are analysed. FEA-SEA simulation models are used and results are compared. The paper concludes that good indications could be provided using these methodologies.

Ingelaere [42] and Wuyts [43] pointed out that the investigation of the perceived (dis)comfort has to be performed below $50 \mathrm{~Hz}$ even if frequency below $20 \mathrm{~Hz}$ implies a new single rating indicator. On the same point of view, Blazer [44] notes that the footfall noise reaches its peak below $100 \mathrm{~Hz}$. Nevertheless this topic is very difficult to realize since new in situ measurements standards ISO 16283 [45] includes the low frequency procedures but they are not compulsory yet. Furthermore, the methods provide a $50 \mathrm{~Hz}-5000 \mathrm{~Hz}$ range but any investigation outside this scale is not even possible. As a matter of fact, the new standards include rubber ball impact source outlining that the method is suitable to assess the bare feet walking and children jump. Standards connect these results to human disturbance and offer an international method to realize what Ingelaere and Wuyts suggested.

Their work [43] proposes a very interesting survey on basic design and stereotype errors. The authors clearly state why the sound reduction of a floating floor positioned on a light weight floor provides minor performance: the mass-spring-mass effect is much lighter than in heavy weight constructions.

This fact has to be investigated and clarified: a brief deepening is described below.

The sound reduction on a floating floor $\Delta \mathrm{L}_{\mathrm{w}}$ (see equation (2)) depends on Cremer theory:

$$
\Delta L=30 \log \frac{f}{f_{0}}
$$

where $\Delta \mathrm{L}$ is the impact sound pressure level reduction $(\mathrm{dB}), \mathrm{f}$ is the frequency $[\mathrm{Hz}]$ and $\mathrm{f}_{0}$ is the resonance frequency $[\mathrm{Hz}]$ of the spring-mass system expressed by:

$$
f_{0}=\frac{1}{2 \pi} \sqrt{\frac{s^{\prime}}{m^{\prime}}}
$$

where s' is the apparent dynamic stiffness per unit area $\left[\mathrm{MN} / \mathrm{m}^{3}\right]$ of the spring (resilient layer) and $\mathrm{m}^{\prime}$ is the mass per unit area $\left[\mathrm{kg} / \mathrm{m}^{2}\right]$.

Floating floor technology is based on the mass-spring-mass effect as shown in Figure 4: $m_{l}$, called "infinite mass", is the structural and static mass; the spring effect is ensured by the resilient layer (where $k$ is the elastic constant) acting with $m_{2}$ as a "resonant system". The whole system decreases the impact sound pressure transmission emitted by footsteps, object fall, etc. 
(a)

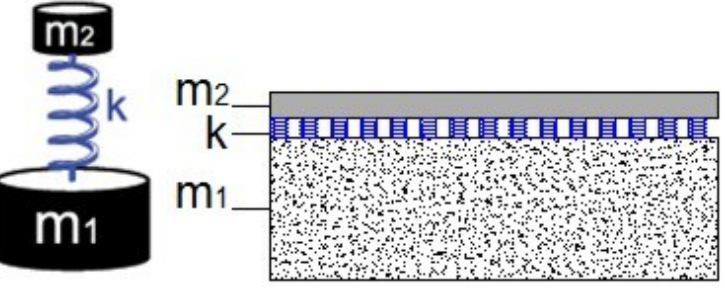

(b)

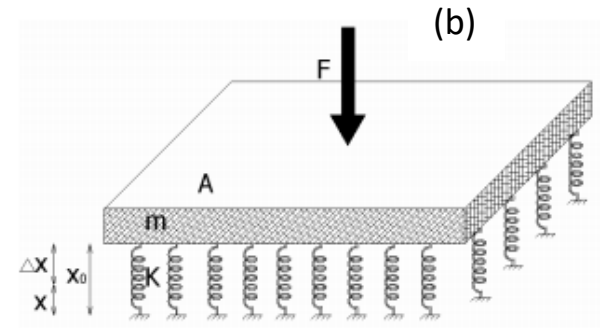

Figure 4: (a) Floating floor representative scheme [46], (b) analytical used model [47].

In light weight constructions various issues are involved:

I. the $\mathrm{m}_{1}$ contribution is quite smaller than the solid floors due to lighter masses involved

II. the $\mathrm{m}_{2}$ influence is very resized compared to traditional heavy weight construction

III. the dynamic stiffness of resilient layers is not always effective.

In the first case the masses difference is easily calculated. In ISO 12354 [13] and ISO 10140 [48] standards the solid reference heavy weight floor has a mass per unit area at about $300-350 \mathrm{~kg} / \mathrm{m}^{2}$. On the other hand the reference lightweight floors masses are $120-200 \mathrm{~kg} / \mathrm{m}^{2}$; so the difference is about $50 \%$.

In the second case, the usual $\mathrm{m}_{2}$ value is $100 \mathrm{~kg} / \mathrm{m}^{2}$ according to ISO 10140 [48] and EN 29052-1 [49] and in situ realizations normally comply with this rule. In addition, traditions, stereotypes, habits, practices etc. imply the use of different technologies from heavy weight buildings even though the $\mathrm{m}_{2}$ mass is limited and often not efficient.

Because of the same reasons, resilient layers are frequently characterized by higher values of dynamic stiffness with a resulting less efficient sound reduction. It is worthy to highlight that higher values of dynamic stiffness [50]-[55] do not derive from the choice of a recycled or natural resilient layer.

Moreover, in [43] the authors stressed that the ISO tapping machine excites the heavy and light weight floor in two different ways: the former generates higher frequencies whether in the latter more sound power is radiated in low frequency range. Finally, the ceiling fixed on wooden battens contributes to radiate low frequency noise so in this case a suspended solution is suggested.

The aim of Sjöström et al. [56] is to model the human walking using real and simulated floor. A previous work by Bard et al. [57] investigated the direction and deflection of human walking on timber floors. The aim of these two papers is not an easy task because the decision of the correct force profile requires further future investigation. The literature contains multiple force profiles for different walking speed, shoe type and gait and so the authors concluded that a final solid result has not been already achieved.

De Geertere and Ingelaere [58] compared the heavyweight performance - chosen as reference -to the lightweight ones. $A L_{n^{\prime} T, w}+C_{I, 50-2500}$ of $48 \mathrm{~dB}$ is requested as desired parameter for both floor technologies. The authors report that in order to achieve this purpose it is possible to use suspended 
ceilings [35] or adding a concrete or sand slab [59] or a sand-sawdust layer [37]. In the authors' opinion, timber industry will not apply these systems because of cost and/or market issues.

They try to handle this topic realizing a mock-up in order to study the influence of reduced sand layer and line-wise resilient connections between the joists; the solution is then investigated and optimized.

On the same topic, Chung and Emms [60] studied the influence of $8.5 \mathrm{~cm}$ sand-sawdust upper layer determining that it acts as a damping vibration insulator.

\section{Type C}

The cross-laminated timber (CLT) panels are constituted of thin beams or planks laid on the top of each other and high pressure glued in order to form a solid uniform board. Therefore, the horizontal (as well as vertical) partitions seem to behave like homogenous slab. Very few studies are present in literature for this kind of structure. Nevertheless this technology is commonly used in Europe, North America, Australia, New Zeeland, etc.

In his work [23] Byrick presents laboratory tests showing the frequency trend of a $175 \mathrm{~mm}$ bare floor (Figure 5) and then he compares different improvements for noise reduction.

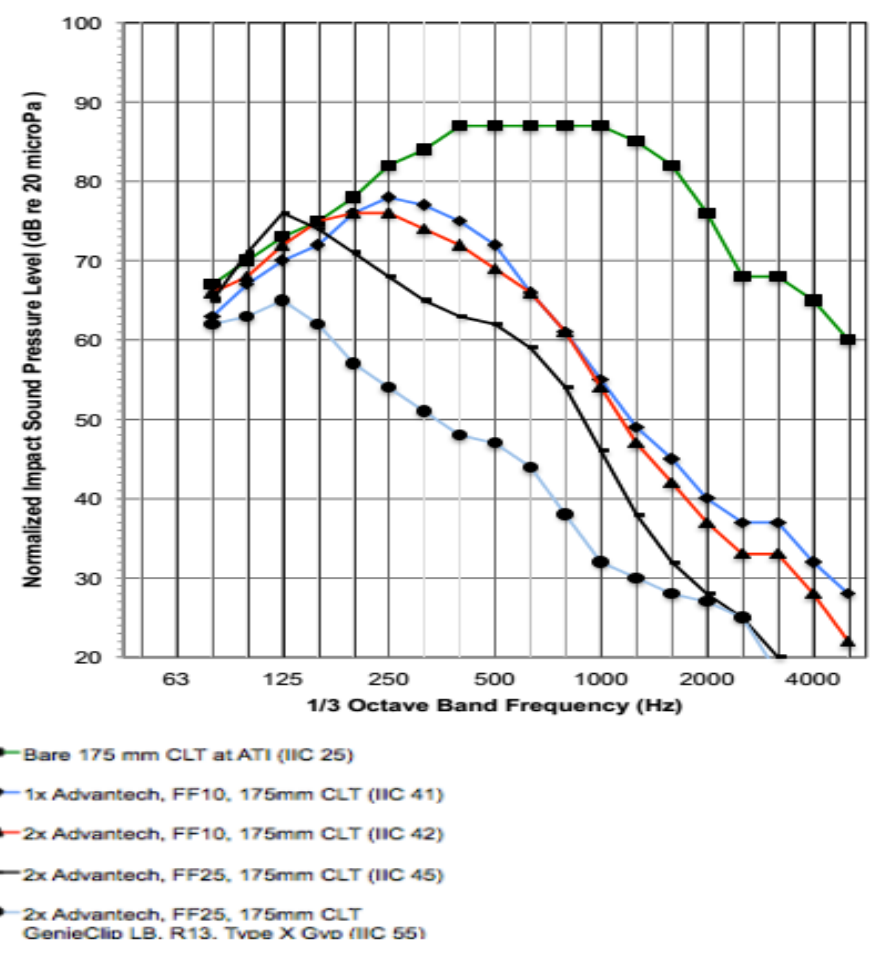

Figure 5 - Laboratory measurements of CLT floor [23].

If the homogeneous mass hypothesis is applicable to $C$ typology, then the $L_{n, w, e q}$ value is obtainable using ISO 12354-2 [13] method:

$$
L_{n, W, e q}=164-35 \log \left(m^{\prime}\right) \quad(\mathrm{dB})
$$


The results are reported in Table 2. It is evident that no homogeneous mass hypothesis could ever be proved on CLT impact noise of bare floors. The main difference lies at high frequencies where the ISO tapping machine excites the timber floor differently to concrete ones [43].

Table $2-L_{n, w, e q}$ values obtained using ISO 12354-2 method and laboratory measurement

\begin{tabular}{|c|c|c|}
\hline description & $\begin{array}{c}\text { ISO 12354 } \mathrm{L}_{\mathrm{n}, \mathrm{w}, \mathrm{eq}} \\
(\mathrm{dB})\end{array}$ & $\begin{array}{c}\text { Measured } \mathrm{L}_{\mathrm{n}, \mathrm{w}, \mathrm{eq}} \\
(\mathrm{dB})\end{array}$ \\
\hline CLT floor. 175 mm thickness [23] & 94 & 85 \\
\hline CLT floor. 135 mm thickness [61] & 98.5 & 88 \\
\hline Concrete floor. 140 mm thickness [62] & 79 & 81 \\
\hline
\end{tabular}

In their work, Völt et al. [24] aim to understand the vibrational response and the sound transmission using vibrational tests and FEM models; the influence of the floating floor and suspended ceiling are investigated too. The results show how any clear correlation between suspended ceiling Eigen modes and the radiated sound power cannot be proven.

Type D

For type D technology only one conference paper appears so far, describing its noise impact and the influence of different added layer or ceilings. For this reason, the interest of technical or scientific literature on this technology is not significant at the moment.

\section{Airborne sound insulation}

Type A

The only work concerning Type A technology belongs to Martins et al. [14] which reports an airborne sound insulation investigation. Here, laboratory tests are performed on the bare structure (TF) and added ceilings (TC1 and TC2). The trends are reported in Figure 6 where the influence of the suspended layers is highlighted. 


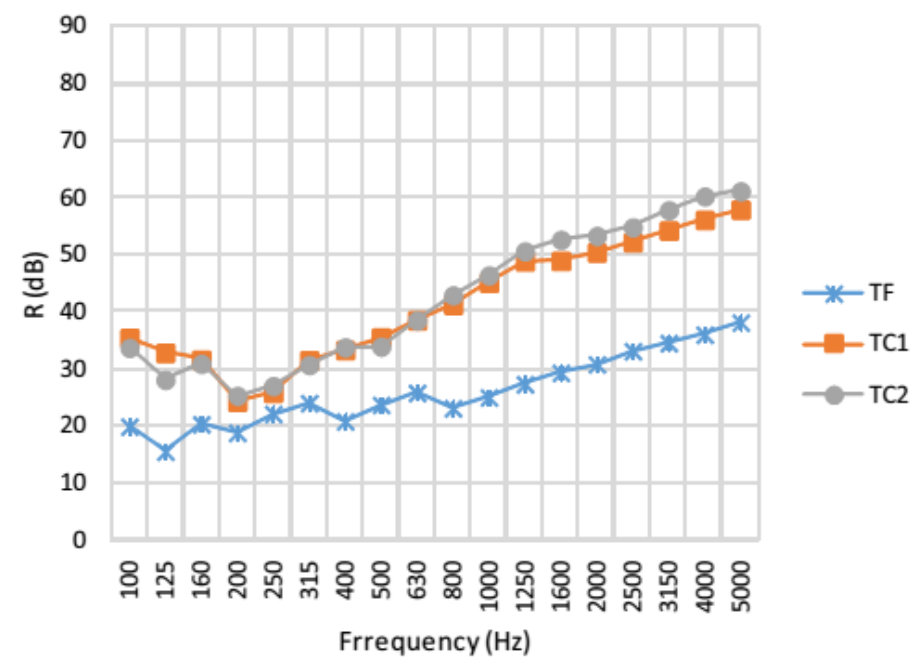

Figure 6 - Laboratory measurements of airborne sound insulation [14].

Type B

The airborne sound insulation is generally less investigated than the impact sound pressure level reduction. Many prediction models are presented and proposed in literature; Mak and Wang [61] analysed over 20 recent papers on this topic and their conclusions are that major contribution for general airborne sound comes from analytical studies. This is true only from the point of view of the number of published works. As a matter of fact, real or simulated test - based paper contains many cases; on the other hand theoretical study provide only well-defined limited topic. But, for lightweight timber partitions the analytical proposed methods often treat, within the same paper, only one or two simplified cases.

As an example Davy [65] proposes a very interesting analytical model to predict air borne sound insulation of single leaf walls, extending the Cremer's theory [66] up to the critical frequency. In the following works, Davy prolonged his previous theory to double leaf cavity walls caused by structure born sound transmission through air gap via line [67] or point connections [68]. The effect of the bending stiffness on laminated panels is studied [69] stating that theory and experiment do not agree because many of the prediction frequencies lie in the critical dip. This is due to Young's modulus and the effective damping loss factor changing in frequency. In the paper, three cases are analysed and the results show that two of them do not comply with the prediction method overestimating the air borne sound insulation at low frequencies.

Many other theoretical examples are included in literature coping with this issue [70] - [73]. On the other hand, measurement-based or computer-aid researches include many cases and stratigraphy. More recent works try to solve the problem using SEA [8], [41], [74], [75], FEM analysis [76], or FEA analysis [8], [77] models trying to cover other possibilities.

Kouyoumji and Guigou [75] reported the activities of AcouBois project where a big database of different typologies (Figure 7) and a new methodology based on partially measured and partially calculated walls, using direct SEA technique was described. The method decomposes the precast 
panels into components, setting modal density and damping loss factor. The obtained results show a good agreement between calculated and measured values.

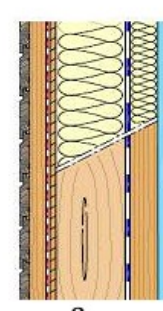

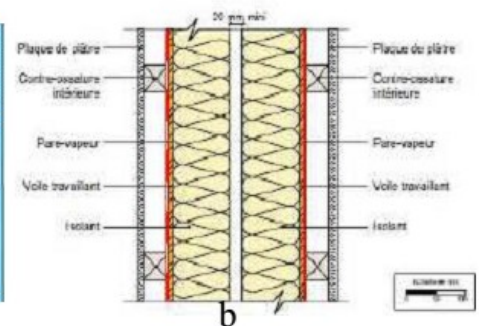

b
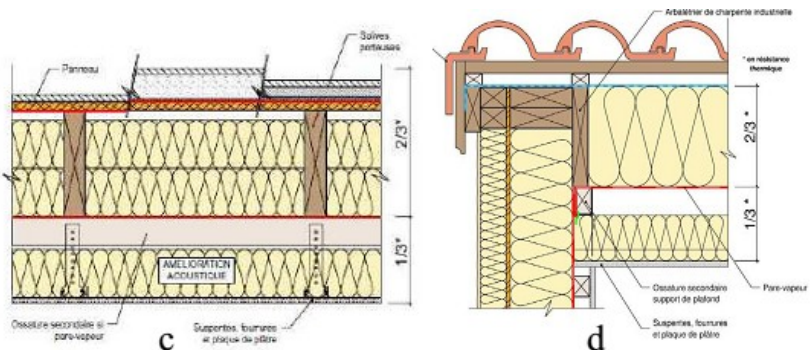

d

Figure 7 - Different typologies tested on AcuBois project [75].

Using numerical FEA analysis, Henning et al. [77] analyse the variations in sound insulation at low frequency range of nominally identical prefabricated lightweight timber panels. The objects of the investigation are the rigid connection between partitions and the influence of the workmanship on the junctions. The final outcomes highlight that the stiffness of the connections influence the sound propagation. The more rigid the connection, the higher velocity levels are found.

Other works study the influence of the flanking transmissions. The available ISO 12354 models are intended to operate within homogeneous and heavy partition range.

These methods are currently under review since they are not applicable to many partitions coupling. New parameters are introduced such as the normalized direction-average velocity level difference, the vibration reduction of the junction, the element attenuation and sound reduction index for resonant transmission. It is evident that new input data are necessary in order to calculate flanking transmission of lightweight junctions.

Crispin and Ingelaere [78] tested, using laboratory measurements, these innovative parameters. The authors suggest how to obtain various factors and compare diverse methods to assess them.

De Geetere [79] measured the newly introduced normalized direction-averaged vibration level difference $\mathrm{D}_{\mathrm{v}, \mathrm{i}, \mathrm{i}, \mathrm{n}, \mathrm{R}}$ in timber frame mock-up in order to provide input data for EN 12354-1 draft. Results demonstrate the difficulties of test flanking transmission down to $50 \mathrm{~Hz}$ caused by shielding issues, negative intensities, bidirectional measurements of vibration level very difficult to realize, etc. Nevertheless the expression contained in the revision of the standard strongly agrees with measurement, therefore no correction is necessary.

A very complete work was conducted by Quirt et al. [80] where an in-depth laboratory measurement campaign is performed. The authors report many measurements and quality rating (see Figure 8) of the possible layer improvements. Starting from the bare partition, they upgrade it step by step and report the single index results for sound insulation (see Figure 9). Furthermore they comment the flanking transmissions, providing many suggestions for in situ realization (see Figure 10). 


\begin{tabular}{|l|c|c|}
\hline Change in Construction & $\begin{array}{c}\text { Typical Effect } \\
\text { due to } \\
\text { one flanking wall }\end{array}$ & $\begin{array}{c}\text { Resulting } \\
\text { Apparent-STC }\end{array}$ \\
$\begin{array}{l}\text { Changing Floor Materials } \\
\text { OSB subfloor } \Rightarrow \text { plywood, or } \\
\text { dimensional wood floor joists } \\
\Rightarrow \text { wood-I joists }\end{array}$ & not significant \\
$\begin{array}{l}\text { Changing Framing } \\
\text { of floors, or } \\
\text { of walls, or } \\
\text { of floor/wall junction } \\
\begin{array}{l}\text { Changing Walls Below } \\
\text { On walls below, } 1 \text { layer } \Rightarrow 2 \text { layers } \\
\text { of gypsum board }\end{array}\end{array}$ & $\begin{array}{c}\text { may be significant } \\
\text { (see next case) }\end{array}$ & $53-55$ \\
$\begin{array}{l}\text { On walls below, mount gypsum } \\
\text { board on resilient metal channels }\end{array}$ & negligible flanking & $54-55$ \\
\hline
\end{tabular}

Figure 8: Typical brief summary of a different layers effect [80].

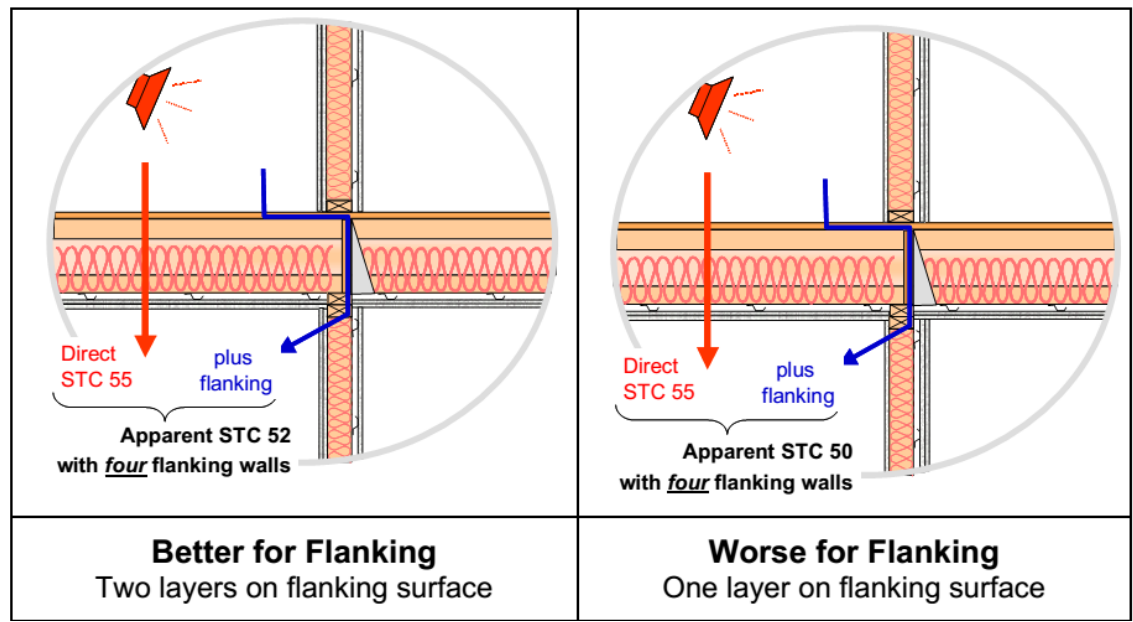

Figure 9: Typical brief summary of a single tested structure [80].

\begin{tabular}{|c|c|c|c|}
\hline & $\begin{array}{l}\text { Worse Floor } \\
1 \text { layer of gypsum } \\
\text { board on resilient } \\
\text { metal channels } \\
\text { spaced @ } 400 \mathrm{~mm} \\
\text { (Direct STC } 51 \\
\text { with no topping) }\end{array}$ & $\begin{array}{l}\text { Basic Floor } \\
2 \text { layers of gypsum } \\
\text { board on resilient } \\
\text { metal channels } \\
\text { spaced @400 mm } \\
\text { (Direct STC } 55 \\
\text { with no topping) }\end{array}$ & $\begin{array}{l}\text { Better Floor } \\
2 \text { layers of } \\
\text { gypsum board on } \\
\text { resilient metal } \\
\text { channels spaced } \\
\text { @600 mm } \\
\text { (Direct STC 59 } \\
\text { with no topping) }\end{array}$ \\
\hline $\begin{array}{l}\text { Worst Case Walls: } \\
\text { Single layer applied to all } \\
\text { walls, one is shear wall }\end{array}$ & 48 & 49 & 50 \\
\hline $\begin{array}{l}\text { Walls with } 1 \text { layer } \\
\text { of gypsum board applied } \\
\text { directly to the studs }\end{array}$ & 49 & 51 & 52 \\
\hline $\begin{array}{l}\text { Walls with } 2 \text { layers } \\
\text { of gypsum board applied } \\
\text { directly to the studs }\end{array}$ & 49 & 52 & 54 \\
\hline $\begin{array}{l}\text { All Walls with } \\
\text { resilient channels } \\
\text { supporting gypsum board } \\
\text { in room below } \\
\text { (Best case: } \text { no flanking) }\end{array}$ & 51 & 55 & 59 \\
\hline
\end{tabular}

Figure 10: Typical brief summary of flanking transmission effects [80]. 
The only weak point of this approach consists in no frequency analysis available throughout the publication: considering the big amount of single parameter and layer measurements, the frequency trend alteration would provide many interesting informations.

Zeitler et al. [81] assessed whether a shear added layer could improve the acoustical performance of walls. After laboratory measurements, they demonstrate that it is beneficial for direct sound insulation and for vertical flanking sound insulation. On the other hand, horizontal flanking insulation shows a worsening in $1 / 3$ octave bands above $125 \mathrm{~Hz}$.

Öqvist et al. [19] investigate the same topic, but focusing on the weight-difference influence. In their field study, 30 nominally identical apartments are tested. Results demonstrate how the elastomer used in floor junction is affected by thickness reduction due to bearing load. The upper floor show better sound insulation than the lower one; this indicates a difference in resilient performance with a resulting sound reduction.

Lentzen et al. [41] use SEA-models suitable for impact noise and for airborne one; their method consists of symmetrically as well as unsymmetrically varying the dimensions of the panels and the coupling length of junction. The authors conclude that it is a good method to provide sound insulation prediction.

De Geertere and Ingelaere [58] also study the airborne sound insulation of vertical panels. They report that moving different layers from centre party wall to external surface avoids leaf resonance, thus enhancing human noise protection.

Type C

The bare CLT airborne sound insulation performances are not investigated in any of the paper correlated to this topic. The reasons could be explained referring to Table 3, where a comparison between ISO 12354-1 model and laboratory measured values is reported. The model agrees with the provided measurement; for this reason no further investigation are needed.

Table 3 - $\mathbf{R}_{, w}$ values obtained using ISO 12354-1 method and laboratory measurement

\begin{tabular}{|c|c|c|}
\hline Description & ISO 12354-1 & Measured $\mathrm{R}_{\mathrm{w}}$ \\
& $(\mathrm{dB})$ & 39 \\
\hline CLT floor. 175 mm thickness [23] & 40.1 & 39 \\
\hline CLT floor. 135 mm thickness [61] & 38.2 & \\
\hline
\end{tabular}

\section{Subjective evaluation}

The literature review on this topic does not divide effects connected to different structures. The main topics, as previously reported, are the low frequency range effects. 
Medved et al. [82] used a mock-up model to investigate how mass effect interacts with low frequency impact noise, showing how the use of pre-mixed concrete gravel acts better than extra boards as impact sound reduction.

Ljunggren and Ågren [83] studied the influence of elasticity in the construction. In order to rise low frequency insulation performance, the use of elastic connections should be introduced. So, multistorey lightweight constructions tests are performed in order to understand if sound reduction and impact sound pressure levels may be improved in this frequency range. The final tests show how vibration junction could be reduced up to $13 \mathrm{~dB}$ in frequency range $50 \mathrm{~Hz}-5000 \mathrm{~Hz}$.

In a similar topic, Bolmsvik and Brandt [84] investigated damping elastomers and their structural behaviour in the joints. The use of a mock-up in two different configurations (with and without damping elastomer material in the joints) allows measurements and comparison with FEM calculation. It is observed that damping varies with frequency. The elastomeric configuration has shown to change significantly the dynamic behaviour of the system, especially at low frequency range.

Ryu et al. [85] highlighted that the ISO 717-2 curve [86] is flat at low frequencies of 100-315 Hz. Several general papers, i.e. not strictly related to lightweight building, have been treated this matter over the last years. For example in 80's Bodlund [87] proposed a subjective survey in order to establish the rating curve values for assessing lightweight and heavyweight impact sound insulation in Japan, [89] and Korea [90],[91]. In their work, the authors used laboratory measures to investigate the connection between annoyance and single-number quantities. The results showed how the arithmetic average $\mathrm{L}_{\mathrm{iFavg}, \mathrm{Fmax}}$ measured with fast constant and Zwicker's percentile loudness $\left(\mathrm{N}_{5}\right)$ [92] indicated a good annoyance rate.

Brunskog et al. [93] expressed the hypothesis that the subjective judgment of impact noise is more annoying if the source position can be localized; lightweight structures have a more contained radiation than heavy structures ones; this could be the reason why a lightweight structure is often subjectively judged more annoying than a heavy homogeneous structure. As a matter of fact, for the heavy structures, the reverberant vibration field is dominant and then it has a distributed radiation not allowing source localization. Using laboratory test, listening playback are used both permanent and moving sources, presenting different stimuli. The test results are opposite to the aim of their paper. They conclude that localized factor do not play a major role in the annoyance assessment, even if it is well recognized by all tested subjects.

Likewise, Sato et al. [94] prosecuted their previous work [95] playing the floor impact sound from a ceiling loud speaker in anechoic chamber. The tests are evaluated using Maximum Zwicker loudness. This study intends to investigate the relationship between subjective evaluation on floor impact sounds and measures. The conclusions demonstrate that both Maximum Zwicker Loudness and $\mathrm{L}_{\mathrm{A}, \mathrm{F} \text {,max }}$ can predict annoyance response to floor impact sound of wood-frame construction. The annoyance can vary by situations and repeating times. 
Ljunggren et al. [96] used on site measurements of airborne and impact sound insulation. Besides they use questionnaire to investigate inhabitants' perceptions, developed within European Network COST TU 0901 project [98] and reported in Figure 11.

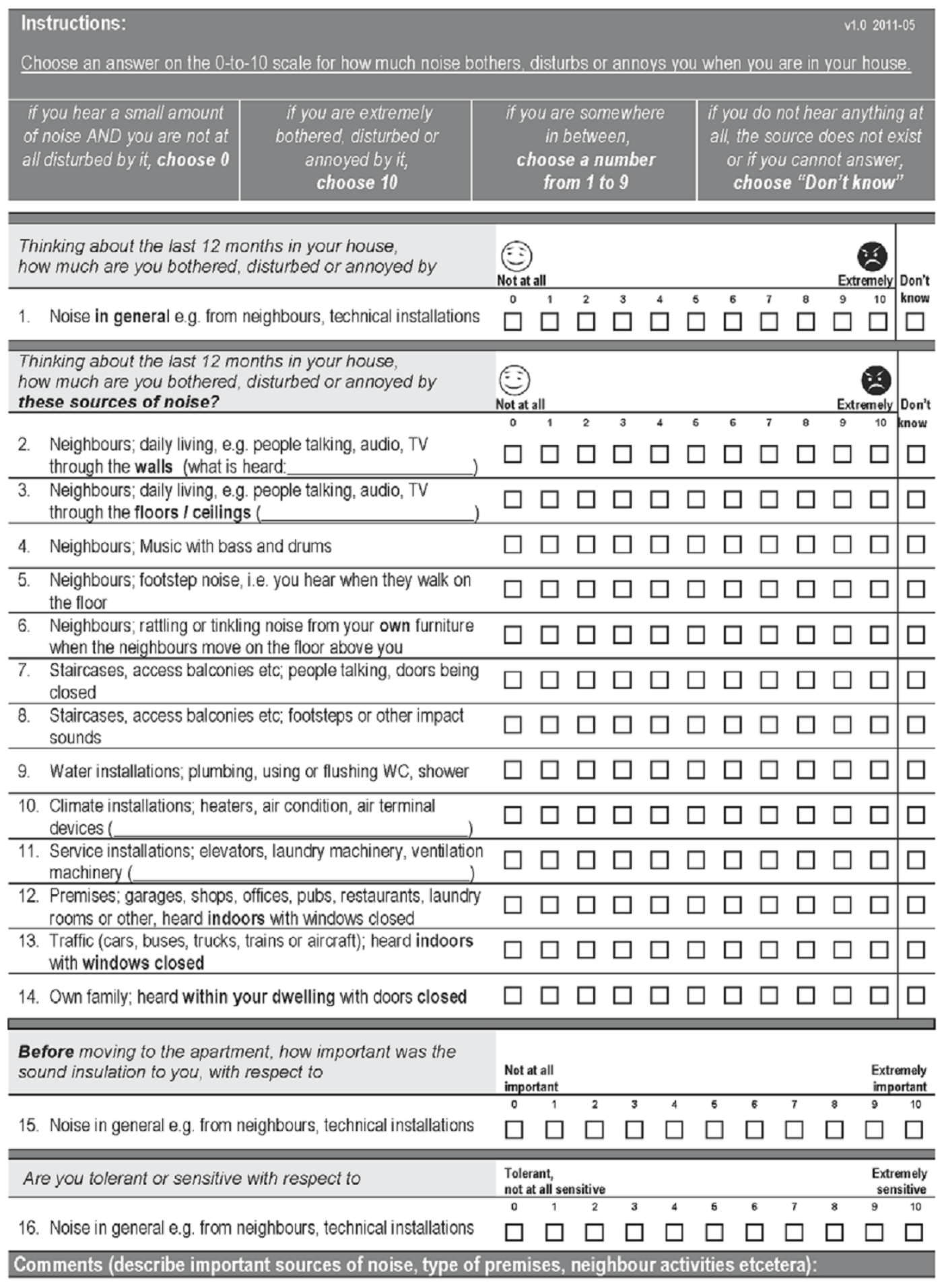

Figure 11: Subjective questionnaire proposed in [98].

The results have demonstrated once again that the source producing the greatest individual annoyance is the impact sound. In Ljunggren et al. opinion, since the single rating numbers 
calculated using ISO 717-2 and ISO 717-1 [99] standards could not connect annoyance and measurements results, they suggest a new spectrum adaptation term which takes into account the relation between the objective and subjective methods.

Liebl et al. [100] used both subjective survey and noise listening in timber constructions in Germany and Switzerland. They report that the annoyance overall is not high but general noise is considered higher than individual noise sources. Thus noise annoyance seems to be a combination of annoyance caused by individual sources. Furthermore the listening tests provide a very interesting outcome: the short-term subjective impression obtained during laboratory assessments corresponds to long-term acoustic impression deduced from inhabitants' questionnaires.

On the contrary, in a succeeding paper Liebl et al. [101] conclude that the short-term evaluation laboratory tests could not substitute long-term results. In this paper two cases out of three demonstrate what previously stated [100] but the third one didn't.

Negreira et al. [102] described an investigation on human walking: acceleration measurements are carried out while a person either is walking on a particular floor or is seated on a chair placed there while someone is walking on the upper floor. The participants fill out a questionnaire regarding their perception and experiencing of the vibrations. A total of 60 people were involved in the subjective tests. Five different floors technologies were tested. The answers provided by participants could be useful to calculate new parameters to determine the best design indicators of vibration acceptability and annoyance.

At the end, it is possible to understand how low frequency noise range is the most disturbing one within sustainable buildings and how its assessment is very difficult to perform [103], [104].

\section{Discussion and conclusions}

It is evident that the acoustic studies on wooden lightweight buildings start from real needing and applications. Most investigated issues are the impact noise and the low frequency insulation and their effects on human perception. The latter topic requires further deepening since a full agreement about usable methods and interpretations of results has not been found between scientists.

As a matter of fact airborne sound insulation is less studied than impact noise reduction since it is of easier solutions and the related problems less probable. Furthermore SEA/FEM simulations are possible and reliable whether impact noise is not modelled yet.

In Table 4 a summary of the results is presented in term of presence of studies on related topics for impact sound reduction and in Table 5 for airborne sound insulation.

Table 4 - Results summary for impact noise reduction

\begin{tabular}{|l|c|c|c|c|c|c|c|c|}
\hline & Parameter & frequencies & $\begin{array}{l}\text { FEM/ } \\
\text { SEA }\end{array}$ & $\begin{array}{l}\text { In field } \\
\text { measurement }\end{array}$ & $\begin{array}{l}\text { Laboratory } \\
\text { measurement }\end{array}$ & $\begin{array}{l}\text { Prediction } \\
\text { models }\end{array}$ & $\begin{array}{l}\text { Added } \\
\text { ceiling }\end{array}$ & Subjective \\
\hline Type A & -- & $\checkmark$ & -- & $\checkmark$ & $\checkmark$ & $\checkmark$ & $\checkmark$ & $\checkmark$ \\
\hline Type B & $\checkmark$ & -- & $\checkmark$ & $\checkmark$ & $\checkmark$ & -- & $\checkmark$ & $\checkmark$ \\
\hline Type C & -- & $\checkmark$ & $\checkmark$ & -- & $\checkmark$ & -- & -- & -- \\
\hline
\end{tabular}




--

Table 5 - Results summary for airborne sound insulation

\begin{tabular}{|c|c|c|c|c|c|c|c|c|}
\hline & Parameter & frequencies & FEM/SEA & $\begin{array}{c}\text { In field } \\
\text { measurement }\end{array}$ & $\begin{array}{c}\text { Laboratory } \\
\text { measurement }\end{array}$ & $\begin{array}{c}\text { Prediction } \\
\text { models }\end{array}$ & $\begin{array}{c}\text { Added } \\
\text { ceiling }\end{array}$ & Subjective \\
\hline $\begin{array}{c}\text { Type } \\
\text { A }\end{array}$ & -- & $\checkmark$ & -- & -- & $\checkmark$ & -- & $\checkmark$ & - \\
\hline $\begin{array}{c}\text { Type } \\
\text { B }\end{array}$ & $\checkmark$ & $\checkmark$ & $\checkmark$ & $\checkmark$ & $\checkmark$ & $\checkmark$ & $\checkmark$ & $\checkmark$ \\
\hline $\begin{array}{c}\text { Type } \\
\text { C }\end{array}$ & -- & -- & - & -- & - & $\checkmark$ & - & - \\
\hline $\begin{array}{c}\text { Type } \\
\text { D }\end{array}$ & -- & -- & -- & - & - & - & -- & - \\
\hline
\end{tabular}

It is evident how the most studied structure is the glulam with boards screwed on top. Type A is the only one with a prediction model for impact noise reduction whether for type C ISO standard could be used, even if some preliminary studies available at the moment [105]-[106]. Once more type D provides no sufficient studies in order to understand its behaviour.

These results highlight the needing of further investigations on these lightweight structures.

An interesting point is shown in Figure 12 and Figure 13. In the former, the number of papers is reported and related to author(s)' origin continent. It is manifest that Europe is the major supplier, followed by Asia and Oceania and then North America.

From the single country point of view, Sweden is the leader followed by Belgium and New Zeeland. It can be concluded that in these nations the acoustic of lightweight buildings research has more financial support and as a consequence more lightweight wooden buildings are presents.

Finally, no researches focused both on duct-borne sound (both from air and from water waste) due to service equipment and to façade sound insulation related to the influence of windows (glazing and materials frame) are currently available. A new paper on this latter topic have been recently published [107], providing a new prediction method for airborne sound insulation and analysing the relationship between transmittance $\left(\mathrm{U}_{\mathrm{w}}\right)$ and airborne sound insulation $\left(\mathrm{R}_{\mathrm{w}}\right)$ values.

Besides, even if the impact noise and vibration reduction is the most studied topic, very few works analyse the bare floor structures.

Future works will though have to focus on the determination of impact sound reduction prediction methods for type $\mathrm{B}, \mathrm{C}$ and $\mathrm{D}$ and method to reduce low frequency noise propagation through timber buildings.

Since floating floor technology won't work, forthcoming studies have to center the attention on experimenting different solutions able to reduce vibrations transmissions.

Future subjective evaluation would be focused on comparison between traditional and timber buildings since people expects similar comfort conditions and does not take into account any possible modification between different constructions. 


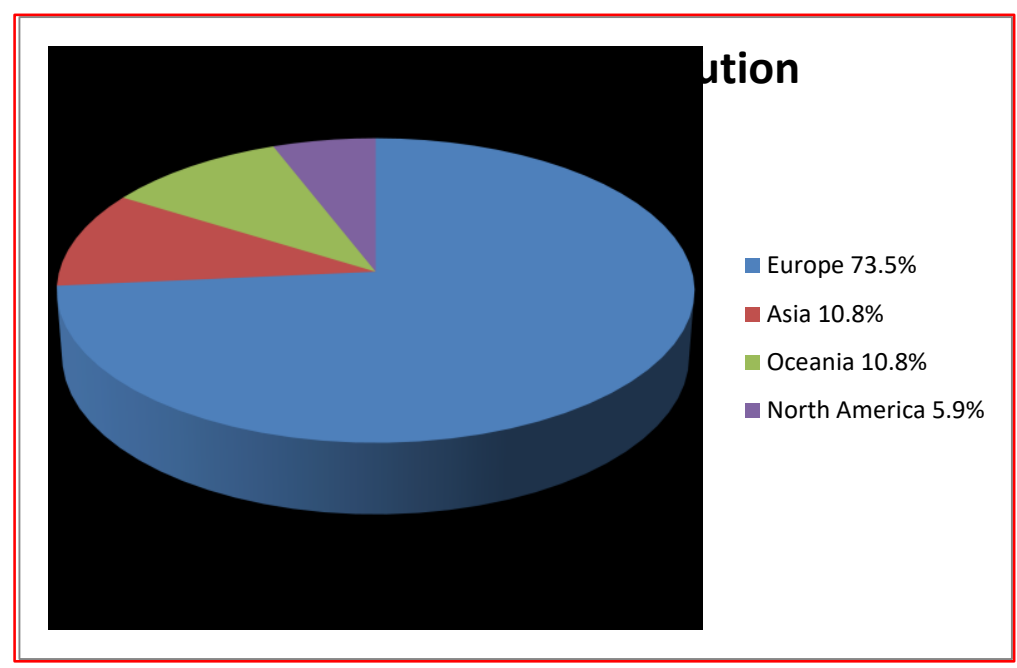

Figure 12: Papers geographical distribution - continent influence.

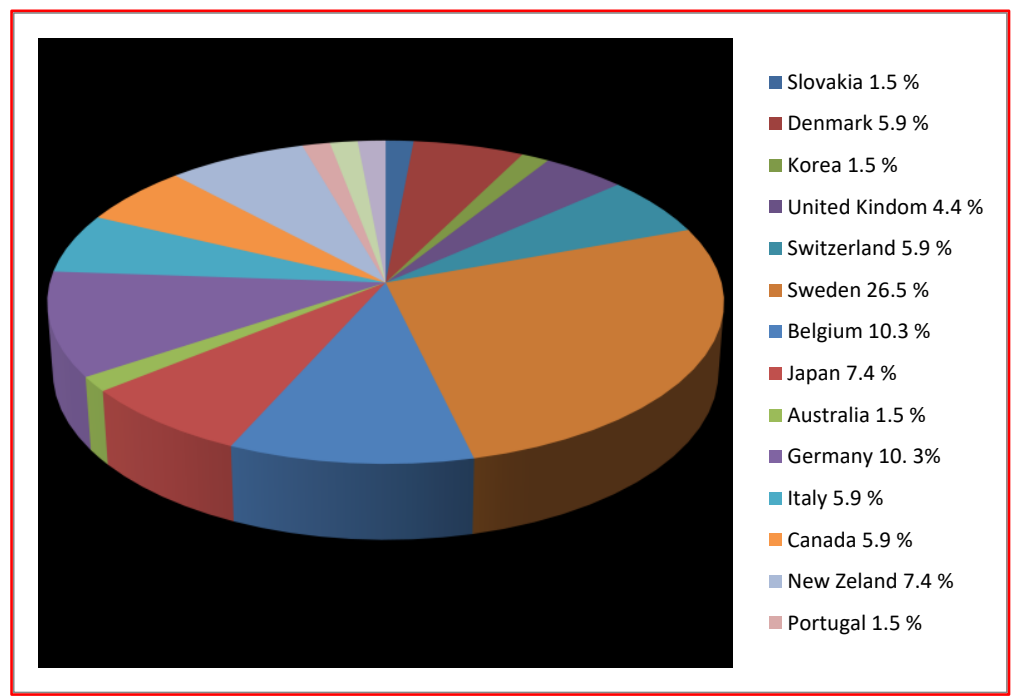

Figure 13: Papers geographical distribution - single country influence.

\section{Acknowledgments}

This research was funded with a Ph.D scholarship by MIUR (Italian Ministry of University) which is gratefully acknowledged and Mr. Andrea Caniato for English form and translations.

We also thank the anonymous reviewers for their advices helping to improve this manuscript. 


\section{References}

[1] De Geertere L, Ingelaere B, A new building acoustical concept for lightweight timber frame constructions, Proc. of Internoise 2014

[2] Caniato M, Bettarello F, Sbaizero O, Schmid C, Recycled materials for noise reduction in floating floors, 22nd International Congress on Sound and Vibration, ICSV 2015; Florence; Italy; 12 July 2015 through 16 July 2015; Code 121474

[3] Ljunggren F, Ågren A, Potential solutions to improved sound performance of volume based lightweight multi-storey timber buildings Appl Acoust 72 (2011) 231-240

[4] Ryu J, Sato H, Kurakata K, Hiramatsu A, Tanaka M, Hirota T, Relation between annoyance and single-number quantities for rating heavy-weight floor impact sound insulation in wooden houses, J. Acoust. Soc. Am. , 129 (5), May 2011

[5] Chung H, Fox C, Dodd G, Emms G, Lightweight floor/ceiling systems with improved impact sound insulation, Build Acousts, Volume 17 Number 22010 Pages 129-141

[6] Bettarello F, Fausti P, Baccan V, Caniato M, Impact sound pressure level performances of basic beam floor structures. Build Acoust 2010;17:305-16. doi:10.1260/1351-010X.17.4.305

[7] Cremer L, Heckl M, Petersson BAT, Structure-borne sound structural vibrations and sound radiation at audio frequencies. Berlin; New York: Springer; 2005

[8] Kouyoumji JL, Prediction Sound transmission loss on lightweight timber framed construction using SEA, Proc. of Internoise, 2013

[9] Lee W, Kim K, Lim S, Imporvement of floor impact sound on modular housing for sustainable building, Renew. Sustain. Energy Rev, 29 (2014) 263-275

[10] Sjöström A, Baard D, Persson K, Sandberg G, Experimental Structural Acoustic investigation of lightweight floor structure, Proc. of Euroregio, 2010

[11] Brunskog J, Hammer P, Prediction models of impact sound insulation on timber floor structures; a literature survey, Build Acousts June 2000 vol. 7 no. 2 89-112

[12] Liebl A, Späh M, Bartlomé O, Kittel M, Evaluation of acoustic quality in wooden buildings, Proc. of Internoise, 2013

[13] ISO 12354-2: Building acoustics. Estimation of acoustic performance in buildings from the performance of elements. Impact sound insulation between rooms

[14] Martins C, Santos P, Almeida P, Godinho L, Dias A, Acoustic performance of timber and timber-concrete floors, Const. Build. Mat. 101 (2015) 684-691

[15] Brunskog J, Hammer P, Design possibilities for impact noise insulation in lightweight floors - A parameter study, Proc. of Euronoise 2003

[16] Brunskog J, Hammer P, Prediction Model for the Impact Sound Level of Lightweight Floors Acta Acust United Acust 89(2):309-322 March 2003

[17] Coguenanff C, Desceliers C, Guigou-Carte C, Jean P, Acoustic performance optimization under parameter and model uncertainties of a wood based floor, Proc. of Internoise, 2013, 
[18] Jarnerö K, Brandt A, Olsson A, Vibration properties of timber floor assessed in laboratory and during construction, Eng. Struc., 82 (2015) 44-54

[19] Öqvist R, Ljunggren F, Ågren A, Variations in sound insulation in nominally identical prefabricated lightweight timber constructions, Build Acousts, Volume 17 n.2 (2010)

[20] Hammer P, Brunskog J, Vibration Isolation on Lightweight Floor Structures Build Acoust, volume 9, number 4, 2002, 257-269

[21] Hagberg K, Bard D, Low frequency sound transmission in multifamily wooden houses, Proc. of Internoise, 2014

[22] Johansson C, Low-frequency impact sound insulation of a light weight wooden joist floor, Appl. Acoust. 44 (1995) 133-147

[23] Byrick W, Laboratory data examining impact and airborne sound attenuation in crosslaminated timber panel construction, Proc. of Internoise, 2015

[24] Völtl R, Schanda U, Kohrmamann M, Buschschmid M, Müller G, Simultaneous operational vibration analysis of different layers of lightweight timber floors, Proc. of Internoise, 2013

[25] Bonnycastle W, Comparing the effect on impact sound transmission of common fire-rated components in wood-frame, open-web truss, multi-family, Proc. of Internoise, 2015

[26] Homb A, Guigou-Carter C, Hagberg K, Schmid H, Impact sound insulation of wooden joist constructions: Collection of laboratory measurements and trend analysis, Build. Acoust., Volume 23, Issue 2, June 2016, Pages 73-91

[27] Liebl A, Späh M, Bartlomé O, Kittel M, Evaluation of acoustic quality in wooden buildings, Proc. of Internoise, 2013

[28] Rasmussen B, Sound insulation between dwellings - requirements in building regulations in Europe, Appl. Acoust. 71 (2010) 373-385

[29] Hiramatsu A, Floor impact sound insulation of wooden three-story school building for full-scale fire experiment, Proc. of Internoise, 2013

[30] Schoenwald S, Zeitler B, Nightingale T.R.T., Prediction of the blocked force at impact of japanese rubber ball source, Acta Acust. united Acust. Volume 97, Issue 4, July 2011, Pages 590598

[31] Nakao T, Tanaka C, Takahashi A, Source wave analysis of impact force on wood based panel floor, Zairyo/Journal of the Society of Materials Science, Japan Volume 37, Issue 416, May 1988, Pages 565-570

[32] Tanaka M, Hirota T, Hiramitsu A, Sato H, Performance for floor impact sound insulation of wood-frame construction housing in Japan, 38th International Congress and Exposition on Noise Control Engineering 2009, INTER-NOISE 2009 Volume 3, 2009, Pages 2071-2079

[33] Hiramitsu A, Effect of change in impact force on heavy-weight impact sound and impact characteristic of heavy/soft impact sources, Noise Con. Eng. Jour., Volume 59, Issue 5, September 2011, Pages 497-504 
[34] Brunskog J, Hammer P, The interaction between the ISO tapping machine and lightweight Floors, Acta Acust United Acust 89(2):296-308 March 2003

[35] COST action FP0702, "Acoustic Design of Lightweight Timber Frame Construction" report

[36] Sjöström A, Baard D, Persson K, Sandberg G, Experimental Structural Acoustic investigation of lightweight floor structure, Proc. of Euroregio, 2010

[37] Chung H, Fox C, Dodd G, Emms G, Lightweight floor/ceiling systems with improved impact sound insulation, Build Acousts, Volume 17 Number 22010 Pages 129-141

[38] Späh M, Liebl A, Weber L, Leistner P, Correlation between subjective and objective parameters of impact noise sources in wooden buildings, Proc. of Internoise, 2013

[39] Späh M, Hagberg K, Bartolomé O, Weber L, Leistner P, Liebl A, Subjective and objective evaluation of impact noise sources in wooden buildings, Build Acoust, Vol. 20, n. 32013 pp. 193 214

[40] Hiramatsu A, Hasemi Y, Kaku T, Floor impact sound insulation of timber three-story school building for final full scale fire test, Proc. of Internoise, 2014

[41] Lentzen S, Born-Van Der Jagt S, Gerretsen E, Sound-insulation and walking-induced vibration models of lightweight junctions, Proc. of Euroregio, 2010

[42] Ingelaere B, Acoustic design of lightweight timber frame constructions - Part 1, Part 2, Part 3, B. November 2012, e-book COST-action FP0702

[43] Ingelaere B, Wuyts D, Impact sound measurements on wooden floors. Project $\mathrm{AH}+$, part 6, Proc. of Internoise, 2013

[44] Blazier WE, Assessment of low-frequency footfall noise in wood-frame multifamily construction. Journal of the Acoustical Society of America, 100(4):2768-2768, September 1996

[45] ISO 16283-2:2015, Acoustics -- Field measurement of sound insulation in buildings and of building elements -- Part 2: Impact sound insulation

[46] Caniato M, Bettarello F, Marsich L, Ferluga A, Sbaizero O, Schmid C, Time-depending performance of resilient layers under floating floors, Const. .Buildi. Mat. 102, 226-232

[47] Caniato M, Bettarello F, Marsich L, Ferluga A, Sbaizero O, Schmid C, Impulse response method for defect detection in polymers: Description of the method and preliminary results, Pol. Test. 55, pp. 78-8

[48] ISO 10140-3:2010. Acoustics - Laboratory measurement of sound insulation of building elements - Part 3: Measurement of impact sound insulation

[49] EN 29052-1:1993 Acoustics- Determination of dynamic stiffness. Materials used under floating floors in dwellings

[50] Asdrubali F, D'Alessandro F, Schiavoni S, A review of unconventional sustainable building insulation material, Susta. Mat. Tec., Volume 4, July 01, 2015, Pages 1-17 
[51] Di Monte R, Caniato M, Boscarato I, Kaspar J, Sbaizero O, Green cork-based innovative resilient and insulating materials: Acoustic, thermal and mechanical characterization, Proc. of Meetings on Acoustics Volume 19, 2013, Article number 040096

[52] Bettarello F, Caniato M, Monte RD, Kaspar J, Sbaizero O, Preliminary Acoustic tests on resilient materials: Comparison between common layers and nanostructured layers, 20th International Congress on Acoustics 2010, ICA 2010 - Incorporating Proc. of the 2010 Annual Conference of the Australian Acoustical Society, Volume 2, 2010, Pages 1096-1101

[53] Schiavi A, Guglielmone C, Miglietta P. Effect and importance of static-load on airflow resistivity determination and its consequences on dynamic stiffness. Appl Acoust 2011;72:705-10. doi:10.1016/j.apacoust.2011.03.009.

[54] Stewart MA, Mackenzie RK. A comparison of the predicted dynamic stiffness of resilient layers with calculated values obtained from the measured acceleration response. Build Acoust 2000;7:297-313. doi:10.1260/1351010001501679

[55] Schiavi A, Belli AP, Corallo M, Russo F. Acoustical performance characterization of resilient materials used under floating floors in dwellings. Acta Acust United Acust 2007;93:47785

[56] Sjöström A, Negreira J, Baard D, Modeling walking on a lightweight wooden floor, Proc. of Internoise, 2015

[57] Bard. D, Sonnerup J, Sandberg G, Human footsteps induced floor vibration, J. Acoust. Soc. Am. 123, 3356 (2008)

[58] De Geertere L., Ingelaere B, A new building acoustical concept for lightweight timber frame constructions, Proc. of Internoise 2014

[59] Zeitler B, Sabourin I, Schoenwald S, Wenzke E, On reducing low frequency impact sound transmission in wood framed construction. Proc. InterNoise 2012,

[60] Chung H, Emms G, Vibration reduction in lightweight floor/ceiling system with a sandsawdust damping layer, Proc. of Internoise, 2014

[61] IFT Rosenheim laboratory test report, n.L07, 12.11.2013

[62] LAB FT laboratory test report, n. 15-850-001, 20.03.2015

[63] Gerretsen E, European development in prediction models for building acoustics, Acta Acoustica, 1994, vol. 2, pp 205-214

[64] Mak CM, Wang Z, Recent advances in building acoustics: An overview of prediction methods and their applications, Building and Environment, 91 (2015) 118-126

[65] Davy JL., Predicting the sound insulation of single leaf walls - extension of Cremer's model, J. Acoust. Soc. Am.,126, 4, 2009, pp. 1871-1887

[66] Cremer L, Theorie der scalldämmung wände dei schrägem eifall, Akust. Z, 7 1942, 81-104

[67] Davy JL., Sound transmission of cavity walls due to structure borne transmission via point and line connections. J. Acoust. Soc. Am. 2012;132, 814-21 
[68] Davy JL., Predicting the sound transmission of double leaf cavity walls due to point and line connections, Proc. of Euronoise 2012, June 2012

[69] J. Davy, A. Cowan, J, Pearse, M. Latimer, The variable effective bending stiffness of lightweight laminated panels, Proc. of Internoise, 2013

[70] Hongisto V, Sound insulation of double panels e comparison of existing prediction models. Acta Acustica united Acustica 2006;92, pp61-78.

[71] Kurra S, Comparison of the models predicting sound insulation values of multilayered building elements. Appl Acoust 2012;73, pp 575-89.

[72] Nakanishi S, Yairi M, Minemura A, Estimation method for parameters of construction on predicting transmission loss of double leaf dry partition. Appl Acoust 2011;72:364-71.

[73] Asakura T, Sakamoto S, Finite-difference time-domain analysis of sound insulation performance of wall systems. Build Acoust 2009;16:267-81.

[74] Wang T, Li S, Rajaram S, Nutt, Predicting the sound transmission loss of sandwich panels by statistical energy analysis approach, J. Vib. Acoust. 132 (1), 1-7 (2010)

[75] Kouyoumji JL, Guigou C, Predicting sound transmission loss of timber framed walls and floors using SEA, in “AcuBois" project of the French wood industry, Proc. of Internoise, 2015

[76] Mahn J, Hopkins C, Filippoupolitis M, Schanda U, Völt R, Krajči L, The optimization of a wooden floor design based on validated finite element models, Proc. of Internoise, 2014

[77] Henning P, Kirkegaard L, Vabbersgaard A, FEA of the variations in sound insulation in nominally identical prefabricated lightweight timber structures, Proc. of Internoise, 2013

[78] Crispin C, Ingelaere B, Laboratory measurements of new quantities necessary for the flanking transmission prediction in lightweight constructions, Proc. of Internoise, 2013

[79] De Geertere L, Experimental investigation on flanking transmission in lightweight timber frame constructions, Proc. of EuroRegio, 2013

[80] Quirt JD; Nightingale TRT, King F, Guide for Sound Insulation in Wood Frame Construction, NRC Publications Archive (NPArC) Archives des publications du CNRC (NPArC), available at http://nparc.cisti-icist.nrc-cnrc.gc.ca/npsi/ctrl?lang=en [accessed 22/2/2016]

[81] Zeitler B, Schoenwald S, King F, Flanking sound insulation of wood frame assemblies with high axial and lateral load bearing capacity, Proc. of Internoise, 2013

[82] Medved J, Ingeleare B, De Geertere L, Impact sound insulation concept for lightweght timber floor, Advanced Materials Research, vol 855, pp 245-251, 2014

[83] F. Ljunggren, A. Ågren, Elastic layers to reduce sound transmission in lightweight buildings, Build Acoustics, Volume 20 n.1 (2013) pp 25-42

[84] Bolmsvik Å, Brandt A, Damping assessment of light wooden assembly with and without damping material, Engineering structures, 49 (2013) 434-447

[85] Ryu J, Sato H, Kurakata K, Hiramatsu A, Tanaka M, Hirota T, Relation between annoyance and single-number quantities for rating heavy-weight floor impact sound insulation in wooden houses, J. Acoust. Soc. Am. , 129 (5), May 2011 

elements -- Part 2: Impact sound insulation

[87] Bodlund K, Alternative reference curves for evaluation of the impact sound insulation between dwellings, J. of Sound and Vib., Volume 102, Issue 3, 8 October 1985, Pages 381-402

[88] JIS A 1418-2, Acoustics - Measurement of floor Impact sound insulation in building element - Part 2: Method using standard heavyweight impact source, 2000

[89] JIS A 1419-2 Acoustics - Rating of floor Impact sound insulation in building and of buildings element - Part 2: Floor impact sound insulation, 2000

[90] KS F 2810, Method for field measurement of floor impact sound insulation. Part 2: method using standard heavy impact sources, 2001

[91] KS F 2863-2, Rating of floor impact sound insulation for impact source in buildings elements, Part-2: floor impact sound insulation against standard heavy impact source

[92] Zwicker E, Fastl H, Psychoacoustics: facts and models, Springer-Verlag, Berlin, 1999

[93] Brunskog J, Hwang HD, Jeong C, Subjective response to foot-fall noise, including localization of the source position, Acta Acust United Acust, vol 97 (2011), pp 904-908

[94] Sato H, Hirota T, Hiramatsu A, Tanaka M, Subjective evaluation of floor impact sound of wood-frame construction dwelling in different living situation, Proc. of Internoise, 2013

[95] Ryu J, Sato H, Kurakata K, Hiramitsu A, Tanaka M, Hirota T, Relation between annoyance and single-number quantities for rating heavy-weight floor impact sound insulation in wooden houses, J. Acoust. Soc. Am. 129 (5), 3047-3055 (2011)

[96] Ljunggren F, Simmons C, Hagberg K, Findings from AkuLite project: Correlation between measured vibro-acoustic parameters and subjective perception in lightweight buildings, Proc. of Internoise, 2013

[97] Ljunggren F, Simmons C, Hagberg K, Correlation between sound insulation and occupants' perceprion - Proposal of alternative single number rating of impact sound, Appl Acoust s, 85, (2014) pp. 57-68

[98] Simmons C, Hagberg K, Backam E, Acoustical performance of apartment buildings resident's survey and field measurements, SP rapport, 2011

[99] ISO 717-1:2013 Acoustics -- Rating of sound insulation in buildings and of building elements -- Part 1: Airborne sound insulation

[100] Liebl A, Späh M, Bartlomé O, Kittel M, Evaluation of acoustic quality in wooden buildings, Proc. of Internoise, 2013

[101] Liebl A, Späh M, Bartlomé O, Kittel M, Comparison of the results of a laboratory experiment and a field study eith regard to acoustic quality in wooden buildings and recommendations for classification of acoustic quality, Proc. of Internoise, 2014

[102] Negreira J, Trollé A, Jarnerö K, Sjökvist LG, Bard D, Determination of vibration acceptability and annoyance design indicators for human response to wooden-floor vibrations, Proc. of Internoise, 2014 
[103] Caniato M., Bettarello F., Schmid C., Fausti P., Assessment criterion for indoor noise disturbance in the presence of low frequency sources, Appl. Acoust. 113 (2016), DOI 10.1016/j.apacoust.2016.06.001

[104] Caniato M., Bettarello F., Fausti P., Marsich L., Ferluga A., Schmid C. Low frequency noise and disturbance assessment methods: A brief literature overview and a new proposal, Proc. of Meetings on Acoust., 28, 032001 (2016); doi: http://dx.doi.org/10.1121/2.0000341

[105] A Di Bella, N. Granzotto, L. Barbaresi, Analysis of acoustic behavior of bare CLT floors for the evaluation of impact sound insulation improvement, Proc. Mtgs. Acoust. 28, 015016 (2016). doi: http://dx.doi.org/10.1121/2.0000420

[106] L. Barbaresi, F. Morandi, M. Garai, A. Speranza, Experimental measurements of flanking transmission in CLT structures, Proc. Mtgs. Acoust. 28, 015015 (2016). doi: http://dx.doi.org/10.1121/2.0000433

[107] Granzotto N., Bettarello F., Ferluga A., Marsich L., Schmid C., Fausti P., Caniato M., Energy and acoustic performances of windows and their correlation, Energy Buil., December 2016, DOI: $10.1016 /$ j.enbuild.2016.12.024 